\title{
The Tyrants of Britain, Gaul, and Spain
}

\author{
A.D. $406-4$ I I
}

I HAVE been lately led, partly in the course of my own reading, partly in the course of my professorial work at Oxford, to make some rather minute inquiries into the history of the early years of the fifth centary, as they concerned the Western lands of the Empire. I have had specially, in view the great invasion of Gaul by the Vandals, Suevians, and Alans, at the end of the year 406, the invasion which led to their settlement in Spain in 409, and the succession of the tyrants or local Emperors who were ever rising and falling at the same time. These two lines of events are connected at every step, though at many points the nature of the connexion has only to be guessed at. And I am not aware of any narrative which tells the whole tale of both in regular order. It would be ungrateful, in dealing with these times, or with any times that they have touched, to forget the labours of Tillemont in a now distant generation and Clinton in one much nearer. Rarely indeed does either of them let slip a fact or a reference on any matter that comes within their several ranges. But Clinton does not attempt a narrative, and we cannot call the good Tillemont's narrative a critical one. Gibbon again, who so largely made use of Tillemont, has, as usual, hardly let slip a single fact; but, as the events of which I speak are in some sort episodes alongside of his main subject, he gives no connected narrative, and the events that I am concerned with are scattered up and down several chapters. To $\mathrm{Mr}$. Hodgkin they come still more in the nature of an $\epsilon$ pisode; from him a full or consecutive account of these matters, which touch Italy and her Invaders only indirectly, could not be looked for. Nor do I find any such connected narrative in any of the German writers on the Wandering of the Nations, as Wietersheim, Pallmann, or Dahn. Of these Wietersheim, edited by Dahn, is perhaps the most helpful ; and Dahn has since, in his Urgeschicllte, come much nearer to a connected story. On the whole Fauriel comes nearer to a regular narrative of the time than any other writer; but his point of view is of course mainly Aquitanian, while the British side is, at least to an English student, quite as important as the Gaulish. 
It is not however of the British side that I wish at present to speak. I trust some day to deal with it in full, either as part of the more general subject of which I am now speaking, or as part of a more general subject still, the Teutonic settlements in our own island looked at in connexion with the Teutonic settlements of the mainland. My work at Oxford may supply me, to some extent it already has supplied me, with opportunities for treating both. But now, as a first contribution to the Hrstorical Review, I wish to speak of one part of the story only, and to put together something like a monograph on the tyrants who arose beyond the Alps in the days of Honorius.

The state of things in the West early in the year 407 follows on an easy chain of cause and effect. Alaric had entered Italy; the legions of the West had been recalled. to meet this pressing danger; the Gaulish frontier was undefended, except by the Frankish allies of Rome; proclamations from Honorius called on the inhabitants of Gaul, free and bondmen alike, to arm for the peace of their country.' On the last day of the year 406-some, reading June for January, have placed it seven months earlier-the great migration took place; the Frankish allies of Rome were defeated, and the three invading nations, Vandals, Alons, and Suevians, spread themselves over the greater part of Gaul, from the Rhine to the Pyrenees. Everywhere that they went they harried, but they nowhere settled, and the south-eastern region of Gaul seems to have been spared; it lay out of their direct lime of march. Saxon harryings in Gaul are also somewhat dimly spoken of ; ${ }^{2}$ and, as the Saxons were at this time the fiercest of freebooters along both sides of the Channel, such inroads are not unlikely to have touched Britain also. But, as a whole, the course of things in Britain, though fairly clear as regards the order of events, is frightfully dark as regards their causes. But we can see that the movement of the legions in Britain was in some way, though in a way not very easy to understand, connected with the great migrations on the mainland. Britain, the other world, was stirred, as Honorius himself was stirred, by the great movement of the Teutonic nations beyond the Rhine; the legions in Britain, forsaken by their Emperor at Ravenna, feared lest the storm which was sweeping over Gaul should spread to Britain also. In such a case they took the law into their own hands. While the Germans and Alans were gathering, while Honorius was calling on the patriots of Gaul to arm, the army of

1. These decrees are in the Theodosian Code. Tit. xiii. de Tironibus, pp. 987-8. They are dated 406 . Clinton pointed out that they referred to the invasion of Gaul. Honorius talks bravely of 'amor patriø,' 'amor pacis et patriæ,' ' utilitas patriæ,' and the like.

2 Prosper Tiro, Peeudo.Prosper, or whatever we are to call him, sums up the whole story thus. ' Saxonum incursione devastatam Galliaram partem IVandali atque Alani vestavere; quod reliquam erat Constantinus tyrannus obsidebat.' This is the annalist who has the well-known entries about Britain and the Saxons. See Hodgkin, i. 278. 
Britain chose an Emperor, a tyrant, of their own, Marcus by name. The step was not new. Britain was already known in the words of Jerome, as a land fruitful in tyrnnts.' There Carausius and Allectus had reigned; thence Maximus had gone forth to occupy Gaul and to threaten Italy; thence the great Constantine himself had gone forth to win the diadem of the world, with the risk that, if he had failed to win it, he too might have been handed down in history simply as one of the same class as Maximus. But Marcus was not as Constantine; he was not as Maximus or as Carrusius. He and his electors failed to agree; he was speedily slain; a man of the province was next chosen, who bore one of the names current in the house of Theodosius. But British Gratian was also killed after a reign of four months, and in the course of the next year, the year of the seventh consulship of Honorius, a choice was made which lasted somewhat longer. The legions chose a private soldier, recommended, we are told, by no merit except that he bore the name of the most lucky of his predecessors in the choice of a British army. Another Constantine was chosen in the hope that his great name would bring good luck with it; and he was hailed as Augustus in the island where the first bearer of it had been first so hailed.'

It is of some importance to notice that these events began before the actual crossing of the Khine by the allied barbarians. The elevation of Marcus marks the effect which the danger, coming but not yet come, had on the legions of Britain. The account of Olympiodóros, that which is most minute in its chronology, fixes it to the year 406. It was before the seventh consulship of Honorius; that is, before the year 407 ; that is, most likely, late in the year 406, when the two Augusti were already consules designati. ${ }^{3}$ But the elevation of Constantine took place in the seventh consulship, that is, after the Rhine was actually crossed. His acts are naturally recorded by several writers who take no notice of his two momentary predecessors. We may almost suspect that they were not heard of in Italy till the next step taken by Constantine gave the movement that had begun in Britain a new character.

Of the acts of Constantine we hear only from his enemies. The portrait that they draw is of course unfavourable; yet he must have differed in some way from his two momentary predecessors; he must at least have had some strength of character to do all that he did, and to bear up for several years against enemies of all kinds and from all quarters. The tale of his first acts is but darkly told ; or rather

1 Ep. zlii. ad Chesiphontem (vol. iv. p. 81).

- Bee and compare the accounte in Olympiodoros, p. 451 ; Zósimos, vi. 2, 3 ; Orogius, vii.; 8oromen, ix. 11 ; Prosper, 407 ; Marcellinus, 111.

- The date is fixed to 106 (see Wietersheim, ii. 160) by the phrage of Olympiodoros,

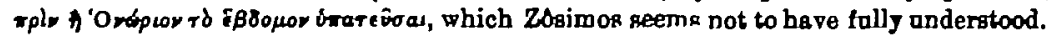


the facts are fairly clear, but it is less easy to judge of causes and motives. Almost the first act of the British tyrant was to forsake his island and to carry the legions across to Gaul. Of his motives for this step we are told nothing. We may read the tale in several ways. Some of the expressions used in describing the elevation of Marcus almost read like a formal secession from Rome and the establishment of a separate empire in Britain. But, if such notions were really held the year before, they certainly had no place in the policy of Constantine. It might rather seem that his object was to preserve the unity of the Empire, at any rate the unity of its provinces beyond the Alps. In this view it might be a wise course not to wait to be attacked in the island, bat to cross to the mainland and to deal a blow at the enemy on what he was fast making his own ground. Britain might thus be saved by a campaign in Gaul. But if this was the motive, the thought of saving Britain must soon have passed away from the minds of Constantine and his soldiers. Whether they cared for such an object or not, the course of things on the mainland soon made it hopeless for them to think of keeping up any relations with the great island. The crossing of Constantine into Gaul thus became the end of the Roman power in Britain.

He landed at that Bononia of northern Gaul, once Gessoriacum, which, though not the starting-point of Crsar, has been in all ages one of the chief points of passage between the island and the mainland. He brought with hirn, it would seem, the whole of the Roman force with which Britain had been held or defended. That force was under the command of two generals, Justinian or Justin and Nebiogast, and it would seem that it was put under their command before the army left Britain. Of their names, the one is clearly Roman, the other clearly Frankish; and we shall presently see that Constantine was on good terms with others of the Frankish allies or subjects of Rome. His stay at Boulogne was not long; but it is hard to trace his course in the early stages of his advance. $\mathrm{He}$ presently gathered under his obedience whatever troops were to be found in Gaul, whether Frankish allies, legionaries who had been left behind by Stilicho, or patriots who had answered the summons of Honorius the year before. The anthority of Honorius was represented in Gaul by the Præfect Limenius and the general Chariobaudes. The name of this last speaks for his barbarian birth; we might seem to see in him an English Herebald. ${ }^{1}$ Of their action at the moment of invasion we hear nothing. These names appear only at a later stage, when we are told that they had fled before the tyrant. But at what stage of his course they fled, and whether they offered any armed resistance to the invader before they fled, on these

1 The atory of Limenius and Chariobaudes comes from a place in Zósimos (v. B2) esrlier in his work, bat describing later events. See Fauriel, i. 55. • 
points we are left wholly in the dark. It seems clear that they did not reach the presence of Honorius till some time in the year 408, which looks as if they did not leave Gaal till Constantine had made some considerable progress on his southern march. On the whole, the chances are against any fighting between the followers of Constantine and any who remained loyal to Honorius. Our authorities are most confused; but the story reads as if so much of Gaul as still obeyed any Roman prince at all submitted to Constantine without a blow.

The mission of the new prince, the object which had brought him from Britain into Gaul, was in some way or other to act against the barbarians who were in full force in Gaul, and who were held to threaten Britain. But it is hard to make out his exact relations, either in war or peace, with the barbarians either within or without the Empire, partly perhaps because our authorities take but little pains to distinguish one set of barbarians from another. According to one version, the army of Constantine saw some sharp service against barbarian enemies, and that seemingly not very long after his landing. We hear of a great battle fought by him or under his auspices, which began with a marked Roman success of which the Roman commanders failed to make the most. The barbarians fled; had the Romans, we are told, pursued, the cnemy might have been cut to pieces. But, as the soldiers or their leaders failed to pursue, the barbarians recovered strength and courage, and by the accession of new forces, they were enabled to hold themselves at least on equal terms with Constantine. Of this fighting we are not told the place, nor the exact time, nor yet the nationality of the particular enemy. But the story sounds as if the fighting had happened on the eastern frontier, against some fresh swarm of barbarians who were striving to make their way into Gaul. For our informant goes on to say that Constantine placed guards on the borders and secured the whole course of the Phine. It is a zealous pagan who speaks; his mind goes back to the days of the hero of his own creed, and he tells us, with some injustice both to the strong rule of Valentinian and to the more recent exploits of Stilicho, that Constantine guarded the Rhine as it had never been guarded since the days of Julian.'

On the other hand, the new Emperor or tyrant stands charged with doing the republic great damage by allowing himself to be many times cheated by the barbarians, by means of treaties, vague, it would seem, in their terms and not strictly kept. ${ }^{2}$ This, we may be sure, refers to the barbarians who were already in Gaul, the Vandals, Suevians, and Alans. Some understanding between them

1 Zósimos, vi. 8.

: Orosius, vii. 28. 'П $\Pi$ i sæpe a barbaris incertis fœderibus illusus detrimento magis reipublice fait.' 
and Constantine there must have been. For two years they and he both carry on their operations in Grul, each, it would seem, without any interruption from the other. And, when the scene of action is moved from Gaul to Spain, each party carries on its operations there also with as little of mutual let or hindrance. It was most likely only by winking at the presence of the invaders and at their doings that Constuntine obtained yossession, so far as Roman troops and Roman administration were concerned, of all Gaul from the Channel to the Alps. Certain it is that at no very long time after his landing, before the end of the year 407, he was possessed of it. ${ }^{1}$ But at that moment no Roman prince could be possessed of much authority in central or western Gaul, where Vandals, Suevians, and Alans were ravaging at pleasure. The dominions of Constantine must have consisted of a long and narrow strip of eastern Gaul, from the Chamnel to the Nediterranean, which could not have differerl very widely from the earliest and most extended of the many uses of the word Lotharingia. He held the Imperial city on the Mosel, the home of Valentinian and the earlier Constantine. Trier, ever ready to rise again from her ashes, rose this time among others, and Constantine may have been, though at a somewhat later time, one of the princes to whom her citizens made their prayer for the restoration of their darling games. Certain it is, from the sure evidence of coins struck there in his name, that he was the acknowledged Emperor in the Treveran Augusta." The palace of Valentinian, the mighty basilica, the venerable church, as yet in its first and untouched state, the bridge that yokes the river sung by Ausonius, all that we look down on from the wooded hills that guard the Imperial head of Grul-all had passed into the possession, and we cannot doubt that it must for a while have beheld the presence, of a third adventurer from Britain.

Of those three adventurers the second had perished; Mrximus was recorded in history simply as a tyrant: but one Constantine had marched from Britain and from Trier to the highest pitch of power and glory, and another might be destined to equal luck. It did not suit the purposes of the new Constantine to establish the chief seat of his power by the Rhine or the Mosel. He could, perhaps he thought, deal more easily with the barbarians beyond the Rhine than with the rival Emperor beyond the Alps. The chief seat of his new dominion must be nearer to Italy. From henceforth we hear of him chiefly or only in the sonth-eastern corner of Gaul, the land which was soon to take a new name from its Burgundian conquerors. The land between the Rhone and the

\footnotetext{
1 See Zosimos, v. 27, 31 ; bat at the former moment he seems not to have been in posgession of Arles.

- See Clinton, 407 ; Jahn, Geschichte der Burgundionen, i. 288.
} 
Alps, whose renowned cities still live to awe and teach us by the greatness of their Roman works, now becomes the main centre of our tale. Italy, Aquitaine, Britain, even Spain, are for us little more than scenes of occasional episodes. Each of the cities by the broad and rushing stream seems called on in these strange times to stand a siege in the cause of some Emperor or tyrant, and commonly to behold his end. And one city, the foremost of them all since Phokaian Massalia had sunk for a while to a secondary place, was specially bound up with the reign and fate of Constantine. Hardly when the first news came of his crossing the Channel, bat rather at the time when his rival of Rome and Ravenna began to take counsel against him, one sign of the nearness and greatness of the danger was that Constantine reigned in Arelate. Indeed it may be that it was not till this great accession to the power of Constantine that Chariobaudes and Limenias at last fled to their master in Italy. For the loss of Arelate was no slight blow; the city into which the adventurer from Britain had entered was a prize indeed. The city that was in after days to give its name to a kingdom was then at the height of its greatness. Its wealth, its splendour, its commerce that brought to it the good things of every quarter of the world, were sung in the verses of poets and recorded in the edicts of Emperors. ${ }^{1}$ Not then, as now, sitting by the side of one mighty stream, but, like Ravenna then, like Venice now, floating on many waters, untouched by the blows which were fast falling on Imperial Trier, Arles, in our day so sadly fallen from its ancient greatness, stood high among the cities of Europe, ready to take the place presently to be granted to it in form, of the head of all the Gauls. Already did the walls of which such mighty relics still abide shelter the dwelling-places of the living; already did the Elysian Fields, now narrowed and dishonoured, shelter the long line of tombs, alike of pagan and Christian dead. Theatre and amphitheatre lifted their bulk, still whole and perfect, the mass of the arena soaring as now above the city, still the home of the savage sports of peace, but not yet itself a house of war, its outline as yet unbroken by the towers reared, some say during the momentary possession of the Arab, some say to hinder his possession from being more than momentary. And if as yet Arles could not as in after days boast of an Imperial church, she could boast of an Imperial palace. Already by the Rhone stood the still abiding tower, a fragment now of a vast pile that has crumbled to ruin, the tower which still bears the name of the earlier Constantine and which now stood ready to become the dwelling-place of his namesake. That the tyrant reigned in the lesser Rome of Ganl ${ }^{2}$ was

1 See the law of 420 in the Theodosian Code; and Decline, i. 85. Cl. Cass. Var. viii. 10.

'Ausonias, Ordo Nobilium Urbium, viii,, 'Gallals Roms Arelas.' 
news that might well strike fear in the greater Rome of Italy and even within the impregnable ramparts and waters of Ravenna. To Constantine himself the possession of this great city seemed the outward sign of the completion of his hopes. Secure, as he deemed himself, on the throne at least of all the Gauls, he began to take steps for founding a dynasty, a dynasty which might call up again the memory of the Imperial house whose greatest name he bore. He had two sons both bearing Flavian names, Constans and Julian. These, like his own, seem to point to the memory of the Flavian house as still cherished in Britain. Of the elder of these sons, Constans, the devout Orosius has preserved the fact, over which he mourns, that he was a professed monk. But, when the aggrandizement of his family was concerned, Constantine had slight regard to ecclesiastical scruples. Constans was called from his monastery to receive the rank of Cosar, and to take an active part in government and warfare. His younger brother at the same time received the title of Nobilissimus. ${ }^{1}$

We are without exact dates; but the news of the landing of Constantine in Gaul, the news of the occupation of Trier and of Arles, could not have been very long in reaching Italy. We are not told whether the beginnings of revolt in Britain, the rise and fall of Marcus and of Gratian, bad ever been heard of at Rome or Ravenna; at any rate they are not recorded as having led to any action on the part of the central power. It was otherwise when the successive messages came that Constantine had landed in Gaul and that he was playing the part of Emperor in city after city, and again that he had passed through the whole land and had set up his throne at Arelate. When the first message came, Honorius, ${ }^{2}$ Emperor and Consul, was at an unusual place for him, namely in Rome itself. Stilicho was at Ravenna. At that moment the friend of Alaric, he was, we are told, making ready for an expedition beyond Hadria, to be carried on in fellowship with the Gothic king, an expedition the object of which was to transfer the cities of Illyricum from the obedience of Arcadius to that of Honorius. His schemes were thwarted by two rumours, by a false report of the death of Alaric and by the true report of the advance of Constantine. This last news was announced to Stilicho by letters from Honorius himself. It was not often, one would think, that the Angustus had news to tell to the Consular, news at least of a graver kind than the revolutions of the poultry-yard. Stilicho now gave up the thought of an Mlyrian campaign, and hastened to consult his sovereign - such is the decent formula-as to what was

\footnotetext{
'Olympiodorros, p. 451; Zosimos, vi. 4. It is Orosius who exclsims, 'proh dolor, ex monacho Cerarem tactum.'

2 The two messages appear in Zósimos, v. 27, 28; the phrase $\tau$ d Bardatos ir

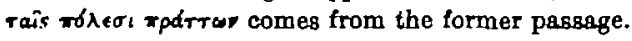


to be done. When Gaul had been attacked by a vast alliance of barbarians, nothing had been done beyond the issuing of proclamations in the province itself. But the rise of a rival Emperor was a more serious matter. The deliberations of Stilicho and Honorius seem to have been carried on into the next year, the year 408 , the year of the consulship of Bassus and Philip, the year which saw the death of Arcadius at Constantinople, the year in which Honorius -if we can give Honorius the praise or blame of any deed good or bad-used, in the phrase of the next generation, his left hand to cut off his right, ${ }^{1}$ by the slaughter of Stilicho himself. But at the beginning of the year Stilicho was still in favour, and Honorius contracted the second of his strange marriages with the daughters of the great Vandal. Disputes with Alaric, now known to be alive, follow; he is ready for warfare in the East, for which Stilicho, with Constantine in Gaul, no longer designs him. Against the tyrant at Arles the counsel of Stilicho now was to send no less a champion than Alaric himself, in the character of a Roman general, to win back the lost provinces for their lawful prince. He himself, Stilicho, will undertake the affairs of the East, while the West-Gothic king represents the true majesty of Rome beyond the Alps."

A day was to come before long when a West-Gothic king was to go on such an errand; but the work for which Alaric was destined was of another kind. Yet another Goth was sent this very year to do the work of Honorius against Constantine. It is hard, though we are chiefly following one authority, to put the facts together out of a most confused narrative. We hear of the growing influence of Olympius at the court of Honorius, an influence used to bring about the downfall of Stilicho. We hear of Honorins at Ticinum, not yet Pavia, while Stilicho is at Bologna. We get a pictare of the Emperor haranguing the troops who are to march, under whose command we are not told, against the tyrant at Arles. A mutiny breaks out, a mutiny which, it is implied, is in some way connected with the intrigues of Olympius against Stilicho. And it is most significant, though we cannot fully understand the significance, that the outbreak of the soldiers led to the slaughter of the two officers, Limenius and Chariobaudes, who had fled before Constantine to Honorius, and who must have joined him quite lately. ${ }^{3}$ They were already in the interest of Stilicho, and on their fate presently follows the fate of Stilicho himself. Yet we read elsewhere that it was at Stilicho's bidding that Sarus, the valiant Goth whose name we so often meet in the history of these times, was sent with a force into Gaul to bring back the land under the obedience of Honorius. The campaign of Sarus is undoubted; but we have no means of fixing the relations between his campaign and the force

1 Proc. Bell. Vand. i. 4, of Valentinian and Aetius.

3 Zösimos, v. 27-81. 
that he held and the contemplated march of the troop that broke out into mutiny at Ticinum.

Anyhow the newly built up throne of Constantine was threatened. Are we to suppose that, after embarking on so hazardous an enterprise, he shrank from personal danger, or that be was conscious of a lack of military skill ? Some accounts represent him, at a later time at least, as more active at the table than in the camp. ${ }^{1}$ Certain it is that it was not Constantine in person who met the army of Sarus in battle. While the barbarians were marching and harrying throughout the land with none to hinder them, two Roman armies met, both doubtless largely made up of barbarian soldiers. The canse of Constantine was defended by his lieutenant Justinian; but the fortune of war was on the side of legitimacy. Sarus gained a victory which carried with it the death of Justinian and the slaughter of the greater part of his army. Of the details of the fight, of the place, of the exact time, we hear nothing; but it is clear that it was fought somewhere in the lower Rhoneland, and it would seem that the routed army could have been only a small part of the forces of Constantine. Where he himself was at the moment we are not told; we know only that after the battle he deemed it wise to secure himself in one of the strong cities of the land, but in one which lies a good way to the north of his newly chosen capital. Many of those cities are greater in old renown, many are richer in abiding remains of Imperial power, but none holds a stronger site, none looks more proudly from its height on the great river at its feet, than the city in which Constantine sought shelter against the attack of Sarus. The walls of the Gaulish Valentia do not still stand in withess of those days like the walls of Arelate and the true Vienna, but in those days the city of the Sagellauni was one of the great fortresses of the land. Its name might suggest the thought of the great prince who had bestowed that nome on the recorered regions of the island that Constantine had forsaken : but, while the Valentia of Britain did indeed preserve the name of Valentinian, the Valentia of Gaul was of older date, it bore the hidden name of Rome herself, and the Valentia by the Rhone might pass as not only the colony but the namesake of the Valentia by the Tiber. There Constantine took his stand. Sarus followed him and laid siege to the strong hill-city. But the Goth went on to sully his hitherto honourable successes by a deed of foul treachery. One of Constantine's generals, the Roman Justinian, had fallen in battle. The other, the Frankish Nebiogast, now made friendly advances to Sarus. Oaths were exchanged; but oaths went for little with Sarus, and Nebiogast was presently put to death. And now, after these successes, the whole enterprise of

1 'Constantinus golm et ventri deditus,' says Renstus Profaturas Frigeridus in Greg. Tar. ii. 9. 
which Sarus was the head breaks down in a strange way, which we should be well pleased to bave explained to us at greater length. The murder of Nebiogast must have happened while Sarus was before Valence, which was no great length of time. To replace his lost generals, Constantine appointed two men whose military reputation would seem to have been higher than theirs. Another Frank, Edobich by name, and Gerontius, who had come from Britain and in whom we can hardly fail to see a name-father of more than one British Gerent, were put at the head of the forces of Constantine. Sarus, we are told, was so fearful of their skill and experience in war that he raised the siege of Valence on the seventh day. His object was now to get back into Italy. The generals of Constantine overtook him with a great force, and brought him to great straits. But the words of our story would seem to imply that thls was rather by harassing his march than by an actual battle. $\mathrm{He}$ escaped into Italy with great difficulty, and that only by help which we should hardly have looked for. Alongside of the new scourges of Gaul, barbarian invasion and civil war, our story implies that an older scourge which seemed to have slept for a while had either lived on or had now shown itself again. The Bagaudæ, the Jacquerie, as they are commonly painted, of more than a hundred years earlier, were at this time in full force, at any rate on the Gaulish slopes of the Alps. Only could they have been a mere Jacquerie? The way in which they are brought into our present story and the way in which they act in it might suggest something of a moro recognized position. We may perhaps be tempted to look with more favour on the view which held that, whatever the Bagaudæ were at the beginning, by this time at least they had put on a character more like that of a national militia.' Whatever they were, they met Sarus, with what object we are not told; but we are given to understand that his passage into Italy was made secure by a timely gift to the Bagaude of the spoils which he had won in his victory over Justinian. Nothing can be more unsatisfactory than this kind of story. We put up with the mere annelist who records victory and defeat without attempting to explain their canses; but here we are told just enough to awaken our curiosity without satisfying it. But at any rate the expedition of Sarus altogether broks down. He had slain, in war and by treason, two generals of Constantine; bat their death seems only to have led to the advancement of more competent successors. Whatever might become of Britain and Italy, the tyrant from the island was now the only representative of Roman dominion in Gaul. His power was at all events firmly established in his own south-eastern corner, which Vandals, Suevians, and Alans, on their march from the Belgian lands to the Pyrenees,

- See Dubos, i. 205; Gibbon, v. 222, ed. Milman. The Bagauda appear again mach later in the century; see Idatius, 441, 443; Faariel, i. 185. 
would be likely to leave untouched. And, as if Gaul had been a separate realm and Italy a hostile land, he strengthened himself against a second invasion from beyond the Alps by placing garrisons in the three chief passes, Cottian, Pennine, and Maritime.

Constantine was now undisputed master of Ganl, of that remnant at least of Gaul which still clave to Rome. Britain he had left behind him. If he aspired to the dominion of Italy, he prudently put off any attempt on that side till he had made himself master of all the provinces beyond the Alps. He was bound, for his 'own ends, to extend his dominion from Gaul in the geographical sense to Gaul in the widest official meaning of the word, and to complete his possession of the Gaulish præfecture by the acquisition of Spain. The great peninsula of the West was one of the most flourishing parts of the Roman dominion, and it was the part which had suffered least from barbarian invasion. The legions which were regularly quartered in Spain, and which were doubtless largely made up of natives of Spain, claimed the defence of the land as their special work, and resented any intrusion of strangers as a breach of their local privileges. But the land had commonly been passive in revolutions, and had readily accepted such rulers as bore sway on the other side of the Pyrenees. But at this particular moment, an element had to be reckoned with in Spain which wonld hardly have passed for a political influence in any other province. Spain had given the world a dynasty. Theodosius, like Trajan before him, had come forth to rule the Empire from the most western of its provinces, and to rule it, like his great countryman, so as to leave a memorable name behind him. The sons of Theodosius, princes of Spanish descent, still ruled, or at least reigned, at Constantinople and at Ravenna. The kinsfolk of the Imperial house, though not marked out from other men by titles or offices known to the Empire at large, were men of wealth and influence in their own land, attached to the throne of their Imperial kinsmen, and acknowledged by those kinsmen as men bound to them by the ties of blood. To the mass of the people of Spain it might seem most natural that Spain and Gaul should go together; to the members of the Theodosian house, and to all who shared their feelings, the first object of all was that the land of Theodosius should abide in the allegiance of the sons of Theodosius. Constantine had therefore to look, not so much for any general resistance in arms on the part of the province or its regular defenders, as for whatever amount of opposition in any shape could be stirred up by a few powerful men. But

\footnotetext{
1 The campaign of Sarus comes from Zôsimos, vi. 2. The fortification of the Alpine pesses is mentioned by Sòzomen, ix. 11 (cf. Olympiodôros, p. 451); but he says nothing

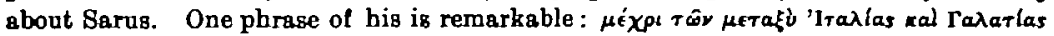

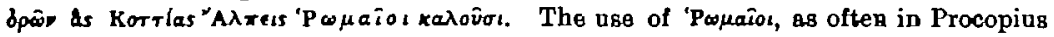
and long after in Constantine Porphyrogenitus, shows the difficulties sometimes felt by those who were Roman in political allegiance, but not Latin in speech.
} 
that opposition was likely to be of a very dangerous kind. Constantine is described as fearing a joint attack from two branches of the Theodosian family, from the Emperor in Italy by the way of the Alps and from his kinsmen in Spain by way of the Pyrenees. Lest his dominion should fall when thus assaulted on both sides, Constantine determined to forestall all attacks from the Spanish side, and at once to begin the occupation of the peninsula. The date is not hard to fix. We are still in the year 408, the year of the campaign of Sarus and of the death of Stilicho. That year saw also the death of Arcadius, and the beginning of the long reign of the younger Theodosius. It saw also the operations of the forces of Constantine in Spain. Those operations, it has been truly remarked, imply some kind of treaty or anderstanding with the barbarians who, it must never be forgotten, were still ravaging through Gaul at pleasure. The relations between him and them, the way in which each side seems to act with no seeming hindrance on the part of the other, form one of the great puzzles of our story. Some of the agreements with the invaders of Gaul which we have seen so darkly hinted at, must surely have taken place at this stage. ${ }^{2}$

But at this stage of the story it is even harder than usual to put the details in their exact order. Our account of the relations of Constantine and his son Constans with Spain has to be put together from several authorities, from the ecclesiastical historian Sòzomen, from the stern preacher Orosius, hiunself a native of Spain, and from the stiff-necked pagan Zosimos, This last may represent Olympiodôros, the best authority of the four, who unhappily fails us at this moment. On the other hand, the local knowledge of Orosius goes for something, and Sózomen seems to have gained, from some quarter or other, a singular knowledge of detail of some parts of the story. There are points on which these writers seem directly to contradict one another, on which at any rate it is very hard to make them agree. But none of them really confirm the version according to which, before Constantine made any attempt on Spain, the kinsmen of Theodosius, at the head of an army of their own levying, successfully defended the passes of the Pyrenees against barbarian attacks during the whole time of the Gaulish harryings of Vandals, Alans, and Suevians. This version, which has been followed by Fauriel, seems to have arisen out of a misunderstanding of the account of Orosius on the part of Isidore of Seville. ${ }^{3}$ There seems no reason to think that the Vandals, Alans, and Suerians, had as yet made any attacks on Spain; they

I Zósimos, vi. 4.

See Wietersheim, ii. 161.

- Soe Pauriel, i. 151. The passage in Isidore (Hist. Wand. at the beginning) is clearly founded on that of Orosius (vii. 28), but with some changes to adapt it to Isidore's misnnderstanding of Orosius. When Orosius says : 'Non assumpserunt adversus 
were still busy with the work of havoc in Gaul. And it seems clear also that the warfare of the kinsmen of Theodosius was waged wholly against Constantine and his son and those barbarians who were in their immediate pay. For a moment the whole peninsula seems to have sabmitted without opposition to the ruler of Ganl and to the officers whom he sent to represent him. But, if so, the submission was only momentary, and the action of the Theodosian family was a rerolt against it. Among them four brothers, bearing the names of Didymus, Verenianus, Theodosius or Theodosiolus, and Lagodius, held a high position for birth and wealth in different parts of Spain. Two of them, Didymus and Verenianus, now raised the standard of legitimacy, the standard of their own house. The two other brothers seem to have taken no part in the enterprise. Didymus and Verenianus, we are pointedly told, did not themselves assume the tyranny in opposition to the tyrant-this, it would seem to be implied, would have been the natural course for men in their position-they strove for their country and for their lawful prince at once against the tyrant and against the barbarians who followed him.' But if two of the four brothers were united as to ends, they were not at first of one mind as to means. It was only after some unexplained differences between themselves that Didymus and Verenianus agreed on any combined action. Lusitania was seemingly the part of Spain in which the brothers had most influence, and that in which they first took up arms. But the natare of the force which they commanded, and the alternations of victory and defeat which they went through, are told very differently in our different versions. In one account we read that they were joined by a regular Roman legion-a legion doubtless formed of soldiers of Spanish birth-quartered on the Lusitanian side of the country. Another account tells us that they had for some time kept at their own cost an irregular army of slaves and pessants. This now did them good service, better service, it is said, than the regular troops, as is not at all unlikely in guerrilla warfare in Spain. This 'rustic army,' as Gibbon calls it, appears unmistakeably a little later in the story ; the only question is whether it came on the field quite so early as this. But it was seemingly this Lusitanian movement, whatever its exact nature, which led Constantine to send his son the Cæsar Constans to put down the Spanish revolt, and to bring its leaders before him in chains. He came at the head of the barbarian allies whom his father had found in Gaul. They bore the name of Honorians, but

tyrannum quidem tyrannidem, sed imperatori justo advarsus tyrannum et barbaras tueri sese pstriamque suam moliti sunt,' the whole run of the story shows that barbari mesns the Honorians, the barbsrians in the service of Constantine. Isidore anderstood it of the Vandsls, Alans, and Buevians.

I Orosing, u.s. 
they were enlisted on behalf of Constantine against the prince whose name they bore. A motley gathering of troops of various nations, Scots, Moors, and Germans, they ranked among the household troops of the Empire; but they were likely to be indifferent as to which of two rival Augusti they drew their swords to support.' Constans took with him the British general Gerontius, and he took with him also, as a civil lieutenant, a man chiefly memorable as the forefather of one of his own descendants. Apollinaris, grandfather of the famous Sidonius of Auvergne, came of a senatorial house which ranked high among the nobility of his own province and of all $\mathrm{Gral}$. The highest office in the Western lands, the prætórian præfecture of the Gauls, was almost hereditary in his house. But he was the first of his line, as his admiring grandson tells us, to embrace the new creed of the Empire and to have the cross signed upon his brow.' He did not scruple to accept his office, seemingly as the successor of Limenius, at the hands of the actual ruler of Gaul, and to help that ruler's son in his attempt to add Spain to his father's dominions. The adhesion of such a man to the cause of Constantine is the best witness to the general acquiescence, to say the least, of the Gaulish lands in the transfer of Imperial power to his hands. The joint march of Constans, Gerontius, and Apollinaris was met at some stage, seemingly on the Spanish side of the Pyrenees, by the irregular army of Didymus and Verenianus, which, by this time at least, was in full action. The object of the brothers was to bar the passes of the Pyrenees against the invaders from Gaul, a work for which Spanish guerrilla troops would be excellently fitted in any age. For this work it would seem they came too late. Their efforts were not indeed wholly without success; they are vaguely said to have put Constans in great danger. But in the end they were routed, and their leaders, Didymus and Verenianus, were taken prisoners with their wives. The other brothers, who were in some other part of Spain, took fright at the fate of their kinsmen, and fled, Theodosiolus to Honorius in Italy and Lagodius to Constantinople. He could hardly have got thither till the latter part of the year, when he found the young Theodosius already the only Emperor in the East. ${ }^{3}$

1 All about the Honoriani or Honoriaoi (se the Notitia Imperii, iii. $39^{*} 40^{*}$ ) is collected by Gibbon, c. xxx. note 29 ; Wietersheim, ii. 161.

= Of him see Sidoning, Ep. iii. 12, v. 9. He gives the fne epitaph with the lines

Hoo sed maxima dignitas probatur,

Quod frontem cruce, membra fonte, pargans,

Primos de numero patrum suorum Secris sacrilegis renuntiavit.

He was, among other marits,

'Liber sab dominantibus tyrannis.'

- The story of these Bpanish campaigns has to be put together from Sozomen, ix. 11, 12 (whose account is the clearest); Zosimos, vi. 4 ; Orosius, vii. 28. None strictly 
Constans now, as a Cæarar ruling in Spain, established his court at Cesaraugusta, the modern Zaragoza, a choice not unconnected with the greater erents which we shall presently mention. He had so utterly cast aside his monastic vows that he had taken to him a wife; whether he had brought her with him to Spain or had found her there, we are not told. He was now summoned by his father into Gaul to discuss the affairs of their common Empire. He obeyed; he left his wife in his Cæsarean palace at Zaragoza, and entrusted Gerontius with the command of the Honorian troops and with the defence of Spain. ${ }^{1}$ He then hastened to his father, taking with him the captive kinsmen of Honorins, Didymus and Veranianus. They were presently put to death by order of Constantine; of the fate of the wives who shared their captivity we hear nothing.

Constantine was now undisputed master, undisputed Emperor, within so much of Gaul and Spain as acknowledged any Roman prince. Some parts of those lands were still harried at pleasure by detachments of the great host that had crossed the Rhine on the last day of the year 406. Some parts, it may be, were throwing off the dominion of Rome altogether. Britain, the land from which Constantine had set forth, was, not so much throwing off the dominion of Rome as slipping away from it without effort on either side. The dominions of Constantine in the West were painfully smaller than the dominions of Valentinian and Theodosius. But within them be had no Roman rival. The master of Italy, far less fully master in Italy than Constantine was master in Gaul, had striven to shake his throne, and he had failed. What then was lacking to him ? Something which it is not easy to define. With all his success, he was still, in the eyes of men of his own time, as he abides in the pages of history, Constantine the Tyrant. The nse of that name in his day had changed sumewhat from its use in the days of the old Greek commonwealth; but the change was no greater than was implied

regards chionological order, and the geographical contradiction is hopeless; but the 'rustic army' does some exploits somewhere in all versions. On the whole $I$ infer,

First, That Constantine sent agents or troops into Spain twice, the second time under the command of his son Constans. This is distinctly asserted by Orosius, and is partly conflirmed by Sozomen.

Secondl 5 , That the movement of the brothers was a rising against the first occupation, and that Constans wes sent to put down their rising. This again is distinctly assarted by Orosius, and several expressions in the other writers (though they tell another story) help to confirm it.

Thirdly, That the main action of the rustio army was directed, seemingly unsuccessfully, towards guarding the Pyrenees. This is distinctly asserted by Orosius, and is consistent with the language of the other two.

Fourthly, That something happened in Lasitanis before the march of the rustic army to the Pyrenees. This is the hardest part of the story. Orosins says nothing about Lusitania at all; Sozomen Bajs nothing about the legion; ZOsimos makes the rustic army fight better than the ragulars. The details soem hopeless; but that the brothers with the rustic army were defeated by Constans and the Honorians seems clear.

I Seo Renatus ap. Greg. Tur. ii. 9. 
in the changed order of things. A tyrant is still one who takes to himself power without any lawfol claim to take it; the name has even less than before to do with his use of power when he has got it. The Greek tyrant had overthrown a commonwealth; the Roman tyrant had set up his own power in the place of the power of an acknowledged Emperor. But the Roman tyrant had means of making his power legitimate which the Greek tyrant had not. The joint rule of several princes was now familiar, and this system made it easy to raise the successful rebel to the rank of a lawful Cesar or Augustus. When the tyrant had won a certain part of the Empire and saw no hope of winning the rest, when the lawful prince kept a certain part of the Empire and saw no hope of winning back the rest, a compromise was easy. The lawful prince could admit the tyrant as his colleague in the Empire, and thus, while raising his rival to the same level as himself, he could at least keep the rank of primus inter pares. The agreement of course, like other agreements, needed not to be kept any longer than was convenient. If either of the new Imperial colleagues found a good opportunity of overthrowing his Imperial brother, of taking his dominions to himself or bestowing them on some colleague whom he liked better, that opportunity was seldom lost. The thing had happened over and over again. The lives of Caransius, of Maximus, of the great Constantine himself, supply many instructive examples.

Constantine then, master of Roman Gaul and Spain, still felt that there was something wanting to his position, and he hastened to make it good. Called to the throne by an army which had shown itself able to maintain him there, he still felt himself the upstart, the usurper, the tyrant, and owned the higher position of the Emperor who had come to the diadem by a line of those adoptions and associations of sons and colleagues which passed for lawful succession. The tyrant therefore sought for the acknowledgement of his claims by the lawful prince; he sought for his admission as a third Augustus to the Imperial fellowship of Honorius and his young nephew in the East. He sent an embassy, an embassy of eunuchs-the soldier from Britain had conformed to the depraved fashion of the time- to the court of Ravenna, asking the Emperor's forgiveness for his taking on himself the Imperial rank. It was not, his commissioners were bidden to say, his own act; the presumptuous step had been forced upon him by his soldiers. It is implied, though it is not said in so many words, that Constantine demanded the confirmation of their choice and his own recognition as an Imperial colleague. Honorins was in no position to resist or to refuse; with Alaric and his Goths at no great distance, it was not for him to plunge into another war which might end as the enterprise of Sarus had ended. A domestic reason also moved him 
-in this matter Honorius himself may have exercised some measure of personal will. His kinsfolk were in the hands of ConstantineTheodosius had brought that news with him; neither he nor Honorius knew that they had been actually put to death before the embassy had been sent, and Honorius deemed that a farourable answer to the demands of their gaoler might be to their advantage. $\mathrm{He}$ therefore acknowledged the claims of Constantine; he sent him a robe of the Imperial purple. The Roman world, so much of it as was still ruled from Ravenna, Constantinople, and Arles, had again three masters. ${ }^{1}$

It would seem that some formality was lacking in this transaction. Or it may be simply that Honorins wes stirred to some sign of enmity when the news of the death of Didymus and Verenianus reached him, when he thus saw how he had been in some sort cajoled into an acknowledgement of the tyrant of Gaul. It is certain that later in the year 409 Constantine sent another message to Ravenna, a message carried this time by a more honourable messenger. Its bearer was Jovius, who is described as a man of high culture and of other merits, but whom we have no means to identify with, or to distinguish from, other bearers of his own and like names. He came to Honorius when that prince was not in a position to refuse anything; Alaric was on the point of laying siege to Rome. For the slaughter of the Spanish captives the new envoy made much the same excuse as the earher messengers had made for Constantine's assumption of the diadem ; it had not been done by any orders of Constantine himself. This statement we may venture to set down as a bare-faced falsehood; even the meekness of Honorius was stirred by it, and the words of our account seem to imply that the person of Jovius was in some danger. But the Emperor was partly at least won over by the arguments of the envoy. With Italy in the state in which it was, it would be wise for him to yield; and if he, Jovius, was allowed to go back in safety to his master, Constantine would presently come to the relief of Rome at the head of the forces of Gaul, Spain and Britain, wherever these last were to be found.?

This promise, whatever was the real parpose of Constantine in making it, leads us for a moment into the midst of the affairs of Italy. We are, as we have seen, in the memorable year of Alaric's second siege of Rome; at that stage of it when the successive ministers or masters of Honorius are stepping into one another's places with amazing speed. The eunuch Eusebius has become the Emperor's chief chamberlain, and Allobich, a barbarian, perhaps a Frank, has been placed in command of the Roman cavalry. The chief authority at Ravenna is naturally in the hands of the eunuch;

'This embessy comes trom OlympiodOros, p. 850; Zosimos, v. 43.

2 The second embassy comes from Zosimos, vi. 1. 
but the brute force of the master of the horse prevails over the subtler influence of the chamberlain; when the colleagues no longer agree, Ensebius is publicly beaten to death with rods under the eyes of Honorius. At this moment Constantine steps in ; we read in two independent narratives that he entered Italy with an army; but we get exactly opposite statements as to the motive which took them thither. In one version he is marching to Ravenna, to confirm or to carry out his engagements with Honorius, that is doubtless to give help to his Italian colleague against the Goth. In the other version, the master of Gaul and Spain sets out to add Italy to his dominicns. We may therefore assume with safety that the one version represents the purpose that was openly avowed, and the other the purpose which was commonly suspected. ${ }^{1}$ There is no reason to suppose any open breach with Honorius so soon after the second embassy; Constantine appears to have assumed the consulship in partnership with Honorius. ${ }^{2}$ And on the whole it is most likely that it was now, when he was at the height of his power, that he raised his son Constans, who might pass for the conqueror of Spain, from the rank of Casar to that of Augustus. ${ }^{3}$. There would thus be four acknowledged Imperial colleagues, Honorius, Theodosius, Constantine, and Constans; the making of Emperors was still for a moment in Roman hands; it was very soon to pass to the Goth.

Thus, in all outward seeming; help was coming from Arles to Ravenna. But it was deemed at the court of Ravenna that such help was likely to be dangerous; it was believed that there were high officials about the Italian Augustus who were ready to displace him in favour of his Gaulish brother. Allobich, slayer of Eusebius, had won power, but not confidence; he was suspected of being in league with Constantine to transfer to him the whole dominion of the West. It rould 'seem that Honorius, as princes sometimes do, conspired against his minister, and found instruments ready to rid him of the suspected traitor. An opportunity

\footnotetext{
1 We have at this point to put together our story from three sources, Olympiodoros (452), Zösimos (v. 48), Sózomen (ix. 12). We must remember that both Sózomen and Zósimos had most likely read Olympiodoros in a more perfect state than we have him now. Olympiodoros gives as the avowed object of Constantine's Italian raid, drat-

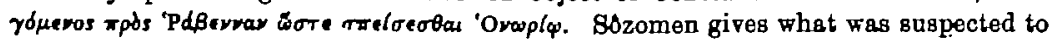

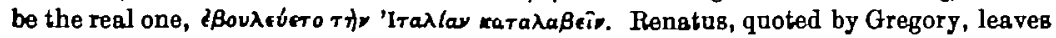
out the Italian expedition and speaks of Constantine as having 'nullum ex Italia metum.' Wietersheim (ii. 166) places the Italian expedition in 410 ; but sarely the whole account of Eusebius and Allobich fixes it to 409 , when Alaric was only threatening Rome.

=For this consulship see Tillemont, v. 570; Gruter, 1072. It is the Greek epitaph of a certain Eusebia at Trier, dated in the eighth consulship of Honorius and the first of Constantine. The consuls in the Fasti are Honorius and Theodosius; most likely the consulship of Constantine was not heard of out of his own dominions.

- Bozomen, ir. 12, distinctly places the elevation of Constans before the expedition to Italy, and he is perhaps not really contradicted by Zosimos, vi. 13 ; cl. Olympiodóros, 458 .
} 
was found as Allobich was riding, according to custom, in a solemn procession before his sovereign. Allobich was cut down by the loyal assassins, and the Emperor, springing down from his horse, gave God thanks in the hearing of all men for having preserved bim from a manifest traitor. So sultan-like had the dominion of Rome become that murder was the only way to forestail or to avenge murder.' The truth of the suspicion against Allobich seems to be confirmed by the fact that Constantine, when he heard of his death on his march, turned back, as if his schemes had become altogether hopeless now that his confederate was gone. He had crossed the Cottian Alps and had kept on the left side of the Po till he reached Verona. He was making ready to turn southward, and to cross the river on his way to Ravenna, when the news of Allobich's death met him. He then went back by the way by which he had come, to find troubles enough in the lands of which he was supposed to be the ruler without adding the defence of Italy against Alaric to his other difficulties.

His troubles had indeed begun before he started for Ravenna. Spain had quietly submitted to the change of rulers in the first instance, and the land, it would seem, might have quietly settled down again after the movement of the kinsmen of Honorias, if Constantine had not wounded local feeling in a very tender point. Spain, as we have seen, had been used to be defended by the arms of her own children. The legions that served in Spain had been Spanish legions, and the keeping of the Pyrenæan passes had been entrusted to what we may fairly call a national militia. Spain, marching on no land but Gaul, had no frontiers of the Empire exposed to barbarian attack; she was not therefore, like Italy and the East, accustomed to see her borders guarded by one body of barbarians hired to keep ont another body of their fellows. ${ }^{2}$ But Constantine and Constans were guilty of the fatul, but not unnatural, mistake of removing the local force, and entrusting the mountain passes to the keeping of their own barbarian allies the Honorians. These troops were further indulged by their commanders, by Gerontius, it would seem, in excessive licence in the way of plunder; they were, above all, allowed to barry the district of Palentia, which, doubtless as having supported the cause of Didymus and Verenianus, was dealt with as an enemy's country. The demand of the Spanish legions that the barbarians might be withdrawn and the old state of things restored was refused, and great discontent arose. To quiet or to suppress that discontent, the new Augustus Constans was sent from Gaul. We have again to details.

'Olympiodoros (452) records the desth of Allobich; S6zomen (ix. 12) gives the

2This notice of the local nsages of Spain is given in different shepes by Zosimos (vi. o), Sozomen (ix. 12), and in the most graphic shape by Orosins (vii. 28). 
put together our story from accounts which are largely fragmentary and which pay little regard to chronological order. But, as far as we can see, Constans went about the time of his father's Italian expedition. It is plain that the new Spanish troables were laid to the charge of the officers whom Constans, on his former visit to the peningula, had left to represent his father, to the charge of Gerontius as the chief of them. He now took with him a general named Jastus, destined, it would seem, to supplant Gerontius, while Apollinaris lost his office of Præfect, which was bestowed on a certain Decimius Rusticus, who had hitherto been Master of the Offices.' The wrath of Gerontius was natarally kindled; and he took the only means of keeping his position which in those days was open to him. There was no safety for him under the rule of Constantine; the proclamation of a rival Emperor was almost a matter of course. But we are so seldom taken behind the scenes, so seldom allowed to study the motives of the actors in this most confused story, that we can merely guess why Gerontius, instead of laying claim to the Imperial dignity in his own person, set up a certain Maximus as Emperor or tyrant. Why did he not place the diadem on his own brow? We see essily why at this very moment Alaric was setting up a puppet Emperor in Italy for his own ends, and why later in the century Ricimer set up and put down Emperors at pleasure. For the days had not yet come for an avowed barbarian. to mount the throne of the Cesars in his own person. Stilicho charged with plotting the elevation of his son Eucherius is a nesrer case to this of Gerontius. But Stilicho was said to come of the stock of the Vandals. The lapse of another generation, the connexion by marriage between this house and that of the Emperors, may have caused the son to be looked on as more Roman than the father. But Gerontius would seem to have been a provincial of the province of Britain, as good a Roman then, by the edict of Antoninus, as any man in Spain, Gaul, or Italy. It is therefore by no means easy to see why when he risked himself and all that belonged to him in a struggle for power, in a struggle against Honorius and Constantine at once, he did not at least ran the risk on his own behalf and in his own name. Whatever were his motives, the fact is clear. It was not himself but Maximus whom Gerontius chose for the dangerous honour. But who was Maximus? That one among our authorities who is on the whole the most trustworthy, but whose evidence has come down to us in the most fragmentary state, seems to call him the son of Gerontius, in which case we should have the closest parallel of all to the alleged designs of Stilicho. He was, it is said, serving among the domestics, the

1 This has to be put together by Zosimos (vi. 51B) and Renatus quoted by Gregory (ii. 9). It is not so much that Zosimos' chronology is really confused as that he men. tions events as they come into his head withont regard to order. 
household troops, doubtless of Constantine and Constans. Other writers speak more vaguely of Maximus as a friend or dependent of Gerontius. In any case, just as with Constantine himself, the name of the renowned British tyrant of the last century may have gone some way towards securing his elevation, though we are also told that Gerontius deemed him a man personally fit for the post. Maximus therefore assumed the purple and held his court at Tarragona. ${ }^{1}$

But it was only a small corner of the peninsula that was ruled by Maximus or by Gerontius in his name. And to maintain himself in that corner, he was driven, as far as we can make out from most unsatisfactory records of most important events, to enter on a scheme of treason of the widest kind, which in its results changed the whole history of Western Europe. He leagued himself with the barbarians, the Vandals, Alans, and Suevians, who had been laying waste the greater part of Gaul for the last two years. He had proclaimed Maximus Emperor; in order to obtain support of some kind for so doubtfal a throne, he did not scruple to invite the ravagers of Gaul to cross into Spain. ${ }^{2}$ He bound himself to them by some kind of formal treaty. Whether it amounted to a regular partition of the peninsula it is impossible to say; but the practical result was to bring about much the same state of things in Spain which there had been for two years in Gaul. The barbarians marched through the greater part of the land and harried at their pleasure, while a corner of the peninsulu, in this case the northeastern corner, the land of Tarragona, remained to the Roman dominion. Within that limit the Roman dominion was now de facto represented by Maximus, as at Arles and in all south-eastern Gaul it was both de facto und in some sort de jure represented by Constentine and Constans.

The effects of the passage of the allied barbarians from Gaul into Spain are of the very highest moment; but for the present we have to look at them only as their presence affected the succession of the contending princes in Gad and Spain. We cannot have a better illustration of the way in which these tyrants rose and fell than the whole story of Gerontius, a story full indeed of striking adrentures. As Constantine bad done by Honorius, so Maximus,

- Olympiodoros (453) calls Marimas the son of Cerontius, which no one would inter from the other accounts in Sozomen (ix. 13), Renatus ap. Greg. (209), and Orosiug (vii. 29) in his Catalogus Tyrannorum. Wietersheim prefers the witness of Olympiodoros, which is doubtless best in itself. But it is hard to see how 8 son could be taken for anything else, while a stranger could more essily be taken for a son.

- We must here compare Olympiodôro (453), Orosius (vii. 28), Sozomen (ir. 113), Zosimos (vi. 5) and Renatus ap. Greg. (ii. 9). The evidence seems to go for direct dealings between Gerontins and the invaders, and his treaty with them is more likely to have followed the proclamation of Maximus than to have gone before it. On the date of the invasion wietersheim (ii. 168). 
or Gerontius in his name, does by Constantine. He reigns at Tarragona, over the fragment of Spain that the barbarians left to him, but without any such formal acknowledgement of his position as Constantine had won from the unwilling Honorius. His immediate enemy was Constantine, whose power in Spain he had overthrown; more immediately still it was Constantine's son Constens, by whom his father had been represented in Spain. Constans, thongh the greater part of his father's forces were under his command, could not stand against the morement which had raised Maximus to power. He and his præfect Decimius Rusticus, who seems to have been specially unpopular, fled into Gaal to Constantine.' Maximus himself did not stir, any more than Honorius; bat Gerontius, in league with the barbarians who had passed into Spain, and bringing with him no doubt not a few of them as his allies and soldiers, set off to follow Constans, and doubtless to win the dominions of Constantine for the prince whom he had himself set up. Constantine made preparations to defend the cities of his obedience and to gain barbarian allies. On this latter errand the Frank Edobich was sent beyond the Rhine to collect a force both of his own countrymen and of the Alemans. Constantine himself, like his rivals, did his main work by deputy. He seems to have shut himself up at Arles, and to have entrusted the active defence of his territories to his son, whose head-quarters were at Vienne." A point so far from the southern frontier, so far north even from Arles, seems strangely chosen when an invading host was on the march from Spain. It has indeed been suggested that the mention of Vienne must be simply a mistake, and that the quarters of Constans were really at Narbonne. Truly Narbo Martius is geographically far better suited than Vienna Allobrogum to be the head-quarters of a ruler of Gaul who is looking for an invasion from Spain. But it is dangerous to reconstruct history in the shape in which, according to our ideas of geographical or military probability, things ought to have happened. Though the tale is told with some geographical confusion, yet Vienne is the only place named where any place is named at all, and I cannot venture to substitute Narbonne. And after all something may be said for the presence of the younger Augustus at Vienne at such a moment. While Constantine kept guard at Arles against the partisans of Maximus, his more enterprising son may well have fixed himself in a city well fitted either as a bulwark against hostile barbarians from central Gaul or as a trysting-place for friendly barbarians from

\footnotetext{
1 The accounts here are very confused : from Olympiodoros (453) one might have thought that Constantine was in Spain as well as Constans, but it seems clear from the other accounts in Renatus and Sozomen that he was in Gaul and at Arles.

The mention of Vienne comes from Sozbmen, and is objected to by Fauriel (i. 101). It is plain that 80zomen did not well understand the geography, but it is daring to change the name, and some of the confused phrases of Renatus and Zosimos might suggest deslings of Constans with barbarians to the north.
} 
beyond the Rhine. The city of the Allubroges was a strong and a noble one. Seated, like her fellows by the broad Rhone, not girded by the waters, like the Arelate of those days, not perched on her steep like the Gaulish Valentia, but nestling as it were in the arena of an amphitheatre of hills, Vienna could then show, whole and perfect, those mighty masses of brick-work whose rains it is not always easy to distinguish from the face of the hills which they so boldly climbed. The lovely relic of pagan days, second only to its fellow temple at Nemausus, was then untouched by age and havoc, perhaps already a honse of worship of the new faith of Rome and Gaul. The obelisk beyond the walls, the shattered theatre within them, the amphitheatre whose site we now faintly trace, the whole range of buildings, rising tier on tier, colonnade on colonnade, must have made Vienna a prouder city to meet the eyes of an advancing enemy than aught that he had hurried by on the Valentian hill, or even among the lagunes of imperial Arelate. It was indeed a prize for which kings might strive which Constans guarded for his father, which Gerontius attacked, it may be, for his son. But again not a word is vouchsafed to us to tell how Vienna fell into the hands of the patron of the new tyrant of Spain. We know not whether the city was stormed or whether it surrendered; we know only that Constans came into the power of Gerontius and was put to death by his conqueror.

From the city defended by the son Gerontius marched to the city defended, or at least dwelled in, by the father. The Briton who had followed Constantine from his island now laid siege to his master of yesterday in the august home that he had helped to win for him. In reading this story, the story of the double siege of Arles, we must bear in mind the topography of the country as it stood at the beginning of the fifth century. The inlets of the sea, which still form so marked a feature on the journey from Arles to the Provençal Aix, were then far more numerous and came much farther inland than they do now. The branches of the river too were then many more than the Great and the Little Rhone that now are left. Arelate was, then as now, parted from the great suburb, far greater then as Colonia Julia Paterna than it is now as the Fauxbourg de Trinquetailles, by the main stream of the river Rhone. That stream was yoked by its bridge, better represented in site by the bridge that now carries the railway than by the bridge that forms the ordinary commanication between city and suburb. ${ }^{2}$ But waters that are now dried up gave both city and suburb a peninsalar shape which they keep no longer. The city itself was washed to the east by a deep inlet of the Mediterranean which formed the p. 211.

' See Lenthéric, La Grece ef l'Orient en Provence, chap. iii., and the plan at

See the verses of Ausoning in the Ordo Nobilium Urbium, viii. 
Statio Navium of Arelate. The Elysian fields lay between its banks and the city walls that rose above them. The plain which reaches almost to the foot of the Little Alps was then a sea; the hills crowned by the holy place of Montmajeur, by the giants' chamber on the height of Cordes, by the rock-hewn dwellings of Les Banx, were then islands in the waters, as Avalon and its West-Sarnn fellows were in the days of 无lfred. Against the city thus fenced in by art and nature two armies marched at the same moment, each hostile alike to each other and to its defenders. For while Gerontius was marching from Vienne by the highway that, like the modern railway, skirts the left, the eastern, bank of the river, another army was on its march from Italy. The lord of Ravenna, however unable to save Rome, could, now that he who had threatened Rome, he who had sacked Rome, had passed away, now that Ataulf ruled the Goths instead of Alaric, find leisure and means to think again of the lands beyond the Alps. And he had those about him who could win back Arles to his obedience, who could rid him alike of the unwelcome colleague by whom Arles was defended and of the avowed rebel by whom it was besieged.

This last distinction, the fact that Constantine held the formal place of a lawful Angustus, while Maximus did not, must never be forgotten. Yet it is hardly wonderful if the distinction between colleague and rebel was not accurately drawn at the court of Ravenna. The acknowledgement of Constantine by Honorius as an Imperial colleague had hardly been an act of the free will either of Honorius himself or of those by whom he was guided. He no doubt personally felt some gradge against his fellow-Emperor on account of the slaughter of his kinsmen; he felt it none the less perhaps because of the pretences by which that slaughter had been feebly excused. And the appearance of Constantine in Italy, an appearance which allowed of so many interpretations, might well be looked on as cancelling all claims on the part of the tyrant of Gaul to be looked on as any longer a fellow-Emperor with the son and grandson of Theodosius. Constantine was now again looked on as an enemy; the enterprise of Sarus was again undertaken with better luck; a force was sent into Gaul to recover the Gaulish provinces, or those parts of them in which the Roman name still bare rule, from the obedience of Constantine to the obedience of Honorius. A new actor in our story appears in command of the host that was sent on this errand.' The likeness of his name to those of two actors whom we bave seen already engaged makes a little more attention needful in following the story. Constantius, at a later time to be the third Emperor of that name, may be looked on as in some sort continuing that great line of Illyrian princes which had given the Roman

1 We get several notices of Constantius in the tragments of Olympiodoros (450, 457, 467). See Hodgkin, i. 404, 420, 424. 
power a renewed life. Born at Naïssus, bearing one of the great names of the Flavian house, if he did not actually share the blood of the elder Constantii and Constantines, he must at least have inherited their traditions. Schooled in the wars of Theodosius, he was the best captain that Rome had left, and he had some merits beyond those of the mere man of war. We see in him traces of the generosity and greatness of soul of an earlier day, and there is something which calls for sympathy in his abiding love for the auguat lady, Roman princess and Gothic queen, whose marriage in the end raised him to the throne. He is first brought into our story as the future husband of Placidia, the futare father of the last Valentinian; bat he may fairly claim a place on his own account as at any rate one of the least evil in a bad time. We are told in a marked way that Constantius at this stage was a man of many virtues, and specially open of hand, while after his imperial marriage he was fallen into covetousness and greediness he loved withal. It was looked on as a deed of justice rather than of cruelty when, at some stage of his career, he caused Olympius, the slanderer of Stilicho, to lose his ears and to be beaten to death with clubs. We have his personal picture, a picture perhaps not altogether attractive. We can sce Constantius with his wide head, his long neck, his large eyes, looking sad and stern as he went forth in warlike array, leaning forward on the neck of his horse, and turning his eyes hither and thither. Men who saw him in such guise said that he bore on him the stamp of one who should one day be a tyrant,' a danger which was escaped by his peaceful admission among the ranks of lawful princes. Bat those who saw him in his lighter hours thought otherwise. At the table and at the banquet of wine he was ever cheerful, and bore himself as the equal of his companions. He would even rise and take his part in merry strife with the jesters who were brought in for the common amusement. Such he was in the hours of peace at Revenna; at Arles he showed himself in his sterner aspect. $\mathrm{He}$ set forth on his errand, taking with him as his seoond in command a valiant Goth who bore the renowned name of Ulfilas, a name whose chief renown has been won in other fields than those of warfare. ${ }^{9}$

Constantius and Ulfilss were sent against Constantine; it is not clear whether they expected to meet with any other enemy. At what point they first drew near to Arles would depend on the road by which they left Italy. They might take either side of the Little Alps and the Durance; they might or might not pass by Glanum with its plain among the hills, with its arch and its still abiding monument. But we may best conceive them skirting

1 Olympiodôros (iv. 67): đầ

2 The two generals come from Olympiodoros and Prosper (411), and SAzomen mentions Ulfilas afterwards, though not now. 
the roots of the Mount of Victory of Gaius Marius, as passing through the city of Sextius with its health-giving waters, a.s passing on by the Stony Plain, thick with the artillery which Zeus himself harled down to the help of his valiant son, and which the traveller who threads the streets of Arles might wish that he was not so often called on to trample underfoot. In either case the last stage of their journey would be the same; they would draw near the city from the north-east; their approach would immediately threaten the Gaulish Gate with the palace of the Constantines rising to their right, while the huge mass of the amphitheatre, taken within the city and taught, like the lesser amphitheatre of Rome, to form part of its defences, rose in its vast balk yet more proudly to their left. We would fain know whether it came on them as a surprise to find that they had to deal with two enemies, within and without the city. It was a strange errand on which the army of Constantius had come. Their march had led them to a besieged town, but they did not come to relieve it; their object was not to deliver bat to capture; only they were for a moment hindered from capturing because yet another power had stepped in before them to besiege. As the troops of Gerontius had come from the direct north, their last stage must have been the same as the last stage of the march of Constantius. The army of Italy must have found the army of Spain actually encamped before the very gate by which either of the roads, one of which they must have taken, would lead them to the walls. Here there was an enemy to be dislodged before they could throw up a bank or shoot an arrow against the city itself. Those who attacked and those who defended Arles were alike traitors to the lawful Emperor whom Constantius served. Constantine the tyrant was within; Gerontius the general of Maximus the tyrant was without. If the soldiers of Italy would discharge the errand on which they had been sent, themselves to besiege Arles and to arrest its Emperor, they had first to deal with those who had come out of Spain on the like errand. The work was not a hard one. It may be that the soldiers of Geronting were in some way moved by the thought that the army of Constantius was the army of a lawful and undisputed Emperor. It is certain that Gerontius had by the sternness of his discipline kindled disaffection in his own ranks.' The greater part of his forces forsook him and followed the banners of Constantius. He himself with a small party escaped into Spain. We must presently follow him thither to listen to the thrilling tale of his last hours; for the present there is more serious work amongst the streams and the lagunes of Arles.

By the flight of Gerontius and his few companions the army of Italy, the army of Constantius, had taken the place of the army of Spain as the host to whose lot it fell to besiege Constantine in Arles.

' Sozomen, ix. 13; Olympiodoros, 454. 
Through the defection of so great a part of the soldiers of Gerontius, the two besieging armies must have been largely made up of the same men. Meanwhile it will be remembered that the Frankish Edobich, now at all events the best officer in the service of Constantine, had gone beyond the Rhine to seek for allies for his master among Franks and Alemans. His mission was not in vain. Arles did not yield in a moment. Warfare beneath its walls lasted longer than it had lasted beneath the walls of Valence or seemingly beneath those of Vienne. The siege was already in its fourth month when the news came that Edobich was drawing near with a rast and motley host of barbarians to the relief of Constantine.' Constantius and Ulfilas were troubled at the tidings; for a moment they even, like Sarus, made up their minds to leave Gaul and await the enemy in Italy. But the march of Edobich was too speedy to allow this timid scheme to be carried out. The besiegers of Arles were on the left, the eastern, side of the Rhone; Edobich seems to have been marching southward along the western bank. When the news came that he was actually encamped in their near neighbourhood, on the peninsula that is covered by the Julian colony, the furthest point to the north-east of the dreary region of the Camargue, all thought of retreat was cast aside by the generals of Honorias. They determined to face the enemy boldly. They crossed the river to give battle to the new comers.? Both this fact and the scheme of action that was planned between the Roman and the Gothic commander, a scheme which showed no lack either of skill or of daring, seem to show that the host of Edobich could hardly have reached even the wall of the colony, and that the battle must have been fought at some little distance from Arles itself. For the followers of Edobich, unlike the followers of Gerontius, did meet the army of Constantius in open fight. According to the plan arranged between him and Ulfilas, Constantias, at the head of the infantry, awaited the attack of the enemy. Ulfilas, with the horse, seemingly a small body, lurked in ambash at no great distance. The host of Edobich, eager for battle, marched by the hidden foes without suspecting their presence, and met the troops of Constantius face to face. At a given signal Ulfilas and his horsemen dashed out of their lurking-place, and charged straight on the rear of the enemy. The battle was at once decided; the barbarian host was broken; 8 some fled, some were slain; the more part threw down their arms, craved for mercy and received it. Edobich fled : he had, in old Teutonic guise, like Englishmen ages

I I ventare to take a date from Renatus and a fact from the other writers. The account in Sozomen seems quite coherent and probable, as that of Renatus may have been if we had his fall text; but instead of Edobich he brings in Jovinus, which utterly confuses the story, and it is clear trom all the annalists that the usurpation of Jovinus was not till after the death of Constantine.

1 The battle comes from 80zomen, our chiel authority just now. 
after, waged the actual battle on foot; the horse was but a means to take the warrior to and from the field. When the day was lost, like the traitors at Maldon or the vanquished remnant on Senlac, he mounted his horse and rode for his life. Not far. from the place of battle was the country-house of one Ecdicius, a man whom Edobich deemed a friend, one to whom he had in former days done many good offices. With him he sought shelter. But in the mind of Ecdicius there was no place for the thought either of hospitality or of thankfulness. He smote off the head of the benefactor who craved his help, and carried it to the camp of Constantius in hope of 8 reward. The general who could strive for mastery with professional buffoons was ready with a grim joke, though a joke whose point is a little dark.' Constantius took the head of Edobich, and said that for the deed of Ulfilas the republic owed its thanks to Ecdicius. But when the murderer showed signs of wishing to stay in his company, Constantius bade him begone; the presence of one who had so evil entreated his guest was not good for him or for his army. And so the man who slew his friend in the day of danger was sent away empty by the man who refused to reward crime even when he gained by it.

The overthrow and death of Edobich sealed the fate of Constantine. Seeing no longer any hope of empire, nor indeed of life if he still laid claim to empire, he laid aside his diadem and purple; he betook himself to a church, already perhaps a church of Saint Trophimus, for sanctuary. He there found a bishop who perhaps deemed that in such a case he might dispense with the precept to lay hands suddenly on no man. Constans, son of Constantine, had of a monk become Cøsar ; Constantine himself was now of an Augustus to become a Christian presbyter. In that character he deemed that his life at least would be safe. But no great hardness was to be feared from Constantius. The defenders of the city, on receiving the general's oath for their safety and for that of their fallen prince, threw open their gates, and the people at Arles at least had no need to complain of any breach of faith on the part of the conqueror. No blood was shed by Constantius. But Constantine and his younger son Julian the Nobilissimus were sent to Ravenna to abide the judgement of Honorius. The Emperor remembered the slaughter of his kinsmen, and he did not hold himself bound by the oath of his general. Messengers

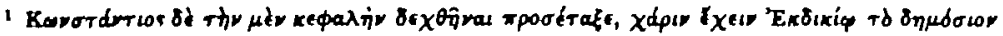

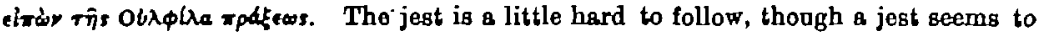
be meant, bat it is hardly needful to transpose the two proper names, as was saggested by Valois. The word squ$\delta \sigma \omega r$ is of more importance, as it clearly translates respublica, the name constantly applied to the Empire long after this time, and which is sometimes a little startling in the mouths of those who were not its sabjects. Its uso seems also to show that we have a literal translation of the actual words of Constantiue.
} 
of death were sent to meet the prisoners, and the priest Constantine and his son were behesded at some point of their journey either on the Mincio or at some point nearer to Ravenna.'

Just at this stange of our story we cannot complain of any lack of personal incident. We part for a moment from the meagre entries of annalists and from fragments pieced together from this source and that, to listen to such a story as the fate of Edobich and its punishment. But the story of the fate of Edobich, stirring as it is, is tame compared with the thrilling talle of the fate of Gerontius. Fleeing, as we have seen, from Arles, he betook himself to Spain, deeming that there at least he might reign in the name of the tyrant of his own making. Bat his hold on the Spanish province was gone. The troops that had been left in Spain scorned the commander who had fled. They plotted his death, and besieged him in his own house. He had with him his wife Nounechia, a few slaves, and a faithful Alan. In one version he too is a slave; in a more likely shape of the story he is an honourable companion in warfare. The most detailed account of the death of Gerontius comes from an ecclesiastical historian who seems suddenly to take up a character oddly mingled between a pagan philosopher and a writer of romance. ${ }^{2}$ Gerontins and his few comrades, sttacked by night, defend themselves from the upper stage of the house, which we must conceive as a strong tower capable of offering some effective resistance. Not a few such miniature fortresses in Ireland and in the border shires of England will enable us to call up the scene. Through the embrasures of the battlements of his pele-tower, sheltered no doubt by the wooden roof coming down on the battlements, Gerontins, his Alan friend, and seemingly the slaves also, did no small execution among the assailants. Themselves almost beyond the reach of missiles, they shot at the besiegers till three handred of them were slain, when their stock of arrows failed them. What follows we should hardly believe if it came from any lighter source than an ecclesiastical history. It was night, and for a while the attacks of the besiegers seem to have cessed. The slaves escaped from the house; Gerontius, and therefore, we may suppose, his wife and his faithful comrade, might have done the same. But Gerontius, restored to his wife, like Odysseus, after absence in the wars, could not bring himself, even when the lives of both were at

1 The fate of Constantine is recorded by Olympiodoros, Renatus, Orosius, and all the annalists. It is not wonderful that those who were not telling the story with the same fulness as Sorzomen should have forgotten the journey into Italy and have fancied that Constantine was put to death at Arles.

2 The most detailed acoount of the death of Gerontins comes from SOzomen. There is a shorter veraion in Olympiodoros, 454. In Olympiodoros, the faithfal comrade is

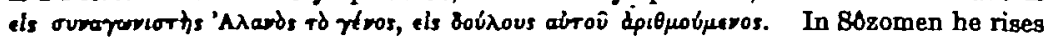
to the rank of ets 'Alasds imithiesos. Burely this is no glave, but a thegn or expdroy, a gesit or bios traipos. 
stake, to leave even a besieged tower that sheltered her. His Alan thegn, his true $\theta \varepsilon \rho a$ it $\omega \nu$-we are hardly wrong if we use either the Teutonic word or its Greek equivalent-tarried with his lord and friend, a doomed groomsman at the renewed wedding. The day dawned, but it brought with it to Nounechia only a morning-gift of death. With the light the besiegers were again active. Their weapons had failed; they now brought fire to the attack, and the three felt that there was no longer hope. But they would not fall alive into the hands of their enemies. First of all, Gerontius smote off the head of the faithful Alan, who offered himself to the stroke, a gesi who wonld not outlive his elder. Then the weeping Nounechia craved a last gift of the husband who was so strangely to die for love of her; let her be slain by his hand rather than pass into the power of others. She thrust herself eagerly against the weapon, Gerontius yielded to her prayer, and the faithful wife died by a stroke of the same sword wielded by the same hand which had ended the days of the Alan. Gerontius now stood alone beside the dead; the stroke of the sword failed him; he then grasped the trusty dagger that hung by his thigh, and drove it into his heart. It might seem that all these details of deeds of which no witness was left could hardly have been inferred even from a more carefal examination of the dead bodies than was likely to be made when wratbful enemies at last made their way into a house which was perhaps already burning. But we must tell the tale as we find it; and specially we must not leave out the comment. Nounechia, so our ecclesiastical guide tells us, a Christian woman, died with a courage worthy of her faith, and left a memory which ought never to be forgotten. It is for some moral ductor dubitantium to rule whether we have here truly a case of 'homicide by necessity.' The ordinary historian may keep himself to the humbler work of wondering at the minute knowledge of the guide whom he has to follow.

So, we are to believe, died Gerontius, the Briton who had helped to set up one tyrant in Gaul, and who had set up another in Spain of his own hand. His former master Constantine and his master's son had fallen with more outward show of civil justice, and their corpses were in the power of the prince in whose interest they were overthrown. According to one strange statement, the heads of Constantine and Julian, as well as the heads of other tyrants earlier and later, were sent from Italy to be set up to the public gaze at Carthage.' It is just possible that such a step may have been taken to remind the furthest parts of the dominions of Honorins of the power and the stern justice of their master. If so, the lesson was in vain. Africa, amongst the other dangerous growths

1 The sending of the heads to Carthage comes from a tragment of Olympiodoros, 456. Mr. Hodgkin (i. 400) suggests that Carthage is a mistake for Milan; if so, it is a strange one. Wietersheim (ii. 159) has no donbt. 
of its soil, could send forth a tyrant as well as Britain and Spain. But for the moment the whole West, so far as it was not actually in barbarian hands, again obeyed the son of Theodosius. Honorius was undisputed Emperor : it was by his profects and officers that the provinces were ruled. Gaul was at rest; the corner of Spain which still clave to Roman rule in some shape submitted to its lawful wielder. Whether the presence of Constantius or of any armed force was needed we are not directly told, but one or two things look like acts of Constantius. Maximus ceased to reign. He was forsaken by the soldiers whom Gerontius had brought from Gaul. By some authority-and whose could it have been save that of the victor of Arles?-those troops were moved, first into Africa and then into Italy. They were most likely on too good terms with the barbarians of Spain, barbarians who were in formal alliance with the deposed tyrant, to be allowed to stay in the peninsala. As for Maximus himsalf, his personal character and conduct had been so little blameworthy that he was allowed to live. If Constantius had any hand in the matter, he had most likely learned that it was better not to trust Honorius with those whose lives he wished to save. But either Maximus still had fears, or he could not bear to live as a subject where he had reigned even in name, or it may be that absence from his former dominions was made the condition on which his life was spared. In any case he fled to his barbarian friends; he was living amongst them when Orosius wrote the last pages of his great homily, and there seoms no reason to accept the statement of a much later writer that, eleven years after the fall of Gerontius and Constantine, Maximus was sacrificed at Rome to celebrate the sixth lustrum of the reign of Honorius. ${ }^{2}$

Honorius then, four years after the revolt of Constantine, is again for a moment free from Roman rivals. Barbarians may lay waste the lands of the Empire, but no tyrant lays claim to its diadem. This state of things was indeed hardly to last a full twelvemonth; the year after the fall of Constantine at Arles saw the assumption of the purple by Jovinus. But the fall of Constantine makes a natural break in the story. Thus far, in Gaul, Spain, and Britain, the tale of the invasion of the barbarians and that of the succession of the tyrants, though tales which are closely connected, are still two distinct tales. Constantine and Maximus clearly leagued themselves with the barbarians; but they were not mere puppets of the barbarians; they were not even set up by barbarian help. Each was set up by a movement in an army which passed for Roman. Bat the tyrants who appear in Gaul in the following years,

' Olympiodoros, 464; Orosius, vii. 29. The words of Prosper, 112, are worth notice. - Maximo in Hispania, regno sblato, vita est conoessa, eo quod modestia hamilitasque hominis affectati imperii invidiam non merebator.'

- Sarcallinus, 422. 
Jovinus, Sebastian, and Attalus-Attalus, already known in Italy, is fresh in Gaul-are far more closely connected with the invaders of the provinces. Attalus was a mere puppet of the Goths, set up and put down at pleasure; his story is merely a part of the marches of Ataulf in Gaul and Spain. Jovinus was set up by Burgandian and Alan help ; his elevation to the Empire and the earliest Burgandian settlement in Gaul are simply two sides of one event. Even Maximus was not in this way the mere creature of the invaders of Spain, though he found it convenient at least to connive at their invasion. With the fall of Constantine then one chapter of the story ends; and I have therefore chosen this point, the end of the history of five remarkable years, for the end of this monograph. The events of those years have an influence which can hardly be exaggerated. In Britain we may fairly aay that the Roman power practically ends; the ground is made resdy for Teutonic settlement. In Gaul, by another process, the ground is made ready for Teutonic settlement of another kind. In Spain Teutonic settlement actually begins. It is hardly too much to say that in the Western lands of Europe the foundations of the modern world were laid in these years. It was at least the events of those years which ruled that Gaul and Britain should be what Gaul and Britain have been in later ages.

Edward A. Freeman. 